\title{
THE CONTRIBUTION OF THE STUDENTS' VOCABULARY, GRAMMAR AND PRACTICE ON THE ENGLISH SPEAKING COMPETENCY OF THE ELEVENTH GRADE OF THE SECOND YEAR STUDENTS OF SMUN 1 IN KUTA
}

\author{
Wendrajaya, $\mathrm{H}$. \\ Language Education Department, Post-Graduate Program \\ Ganesha University of Education \\ Singaraja, Indonesia \\ e-mail: hadi.wendrajaya@pasca.undiksha.ac.id \\ Seken, I K. \\ Language Education Department, Post-Graduate Program \\ Ganesha University of Education \\ Singaraja, Indonesia \\ e-mail: ketut.seken@pasca.undiksha.ac.id \\ Marhaeni, A. A. I. N. \\ Language Education Department, Post-Graduate Program \\ Ganesha University of Education \\ Singaraja, Indonesia \\ e-mail: agung.marhaeni@pasca.undiksha.ac.id
}

\begin{abstract}
This study aimed at investigating 1) the contribution of the students' vocabulary on the English speaking competency, 2) the contribution of the students' grammar on the English speaking competency, 3) the contribution of the students' practice on the English speaking competency, and 4) the contribution of the students' vocabulary, grammar and practice on students' speaking competency. The present research makes use of an ex post facto study with regression analysis. The research was done toward the second year or eleventh grade students of SMUN 1 Kuta in academic year 2013/2014. The population of the study covered 398 students; and the sample was 80, which was determined through cluster random sampling technique. This research used multiple regression analysis with two kinds of instruments, that is, tests and questionnaire. The results show that: 1) there is a significant contribution of vocabulary on the students' speaking competency at $26.8 \%, 2$ ) there is a significant contribution of grammar on the students' speaking competency at $18.1 \%, 3$ ) there is a significant contribution of practice on the students' speaking competency $16.9 \%, 4)$ there is a significant contribution of vocabulary, grammar and practice on the students' speaking competency at $32.6 \%$. Based on the results of this study, the teachers were suggested that they develop various ways to teach vocabulary, grammar and practice to improve the students' speaking competency.
\end{abstract}

Keywords : vocabulary, grammar, practice, speaking competency

\section{INTRODUCTION}

Language is very important to people, because it is used for communication and there are many international languages used for it. As one of those international languages, English is widely used as a universal means of communication among countries in different parts all over the world. For more than a few centuries, it has been used as a Lingua Franca. People from different countries can communicate with one another by using this English Language. Therefore, there are many people all over the world want to learn it because they think they will need it in the future. Nowadays, English is taught as a second or foreign language in all different countries in the world. 
The results of English teaching in one country may not be the same as the one in another country but there have been some common problems in the teaching of English. Widdowson in Brumfit et.al. (1985) states that there is a problem in the teaching of English which has inherited particular prominence over the last few years. The problem is that students, and especially students in developing countries, who have received several years of formal English teaching, are frequently unable to actually use the language, in normal communication, whether in the spoken or the written mode.

Among those developing countries, Indonesia has the same problem in the teaching of English as what has been described by Widdowson. Today in Indonesia, there are more people starting to learn English formally or informally. English is a compulsory subject and taught in Indonesia from Elementary Schools up to universities. The teaching of English at senior high schools focuses on the four language skills, that is, listening, speaking, reading and writing. Besides the teaching of those four language skills, language components are also taught to the students.

There are two language components, namely, vocabulary and grammar. Both of them are important and it is necessary for the students to master them in language learning. Vocabulary can be defined simply as all the words in a language. When the students learn a language, they actually learn words, thousands of them. Whereas grammar can be defined simply as the rules of a language. When the students learn grammar, they actually learn many rules of the language. Students who learn English will usually learn some words and grammar.

In senior high schools, vocabulary and grammar are taught implicitly because they are already included in the teaching of the four skills. However, the results of English teaching in senior high schools are not yet satisfactory. In fact, the students who have passed their senior high schools just understand English but they are not able to communicate in it. Although they are taught the four skills and learn some vocabulary and grammar during their study in senior high schools, they still find it difficult to use or speak English in their daily lives.

Sukrawa (1990) states that the teaching and learning of English for the sake of acquiring communicative performance means that the teacher expects his students to be able to express what they wish to say in accordance with their levels of proficiency in the course, and the meanings of their expressions or sentences can be understood. This means that the main concern is on language performance, namely, the students can manipulate and use the language they have got so far for the purpose of communication. The lower their levels the less sophisticated language users they really are.

In relation to the statements above, Alexander (1993) remarks that learning a language is not only a matter of acquiring a set of rules and increasing a large vocabulary but also enabling the students to communicate in it. The teacher's effort should not be aimed at informing his students about a language, but enabling them to use it. A student's mastery of a language is ultimately measured by how well he can use it, not by how much he knows about it. In this way, learning a language has much in common with learning a musical instrument.

Furthermore, Alexander illustrates that the drills and exercises a student does will enable him to become a skilled performer. A student who has learned a lot of grammar but who cannot use a language is in the position of an organist who has learned a lot about harmony but who cannot play the organ. The student's command of a language will therefore be judged not by how much he knows, but how well he can perform in public. In the end, the students' knowledge of English will be judged by the society at large not on their capacity to write the language but to speak it.

English as a foreign language has an important role in Indonesia. It is because Indonesia is promoting itself as tourist destination to the world. Therefore, tourist industries have developed rapidly and they require a lot of people who are able to speak English well. This, of course, gives opportunities for those who are able to speak English well to get jobs. Especially Bali, as a very well known island among other islands in Indonesia, is visited by many foreign tourists from all over the world who mostly speak English. It means that this is a good opportunity for the students to practise their English. Besides, there are so many learning facilities such as, magazines, newspapers, radios, televisions etc. in English. These learning facilities and opportunities can be considered to be good language environment or exposure for the students to practise their English.

Dulay et al. (1982:13) state that, "The language environment encompasses everything the language learner hears and sees in the new language. It may include a wide variety of situations - 
exchanges in restaurants and stores, conversations with friends, watching television, reading street signs and newspapers, as well as classroom activities - or it may be very sparse, including only language classroom activities and a few books and records".

Dulay et al. (1982) further point out that the quality of the language environment is of paramount importance to success in learning a new language. If students are exposed to a list of words and their translations, together with a few simple readings in the new language, they will perhaps be able to attain some degree of reading skill in language, but listening and speaking skills do not progress. As many high school and college students have learned, to their disappointment, if one is exposed only to classroom drills and dialogues, one may acquire substantial mastery of classroom communication skills but still remain at a loss in other areas of social discourse. And, of course, with no exposure at all, no learning can take place.

Bali is very well-known all over the world. It has so many beautiful tourist destinations. One of them is Kuta which is a worldwide tourist destination. The people who live in Kuta are familiar with the tourists from around the world and have many opportunities to have contacts with them in English. In relation to this, it is expected that the students who live in Kuta are familiar with the English speaking tourists and have more chances to practise their English with them. Therefore, if the students have a lot of practice both in listening and speaking in English, they will have high speaking competency.

However, the students' speaking competency is still an issue to the teachers. It seems their students are still reluctant to use the language in their daily interactions, although they have been taught to learn necessary language skills in senior high schools for several years. It may be true that the students have learned some vocabulary and grammar and there are many opportunities for them to practise their English every day with the tourists but is it really effective to make them learn to speak the language? Do the students benefit from this opportunity and practise their English every day in order to improve their communicative competence and performance? These are the questions that motivated the researcher to carry out this research which aimed to investigate the contribution of the student's vocabulary, grammar and practice on the English speaking competency experienced by the second year students of SMUN 1 in Kuta.

\section{METHODS}

The present research makes use of an ex post facto study with regression analysis. The use of an ex post facto study indicates that the researcher does not try to control or manipulate the variables under investigation, that is, vocabulary, grammar and practice in listening and speaking as independent variables and the students' speaking competency in English as dependant variable. In this investigation, a regression formula were used to analyze the data. The extent of the contribution of the three independent variables on the dependant variable is established by means of multi regression formula.

According to Fraenkel and Wallen (2009), in educational research, population is usually a group of persons (students, teachers, or other individuals) who possess certain characteristics. In some cases, however, the population may be defined as a group of classrooms, schools, or even facilities. In accordance with the definition given by Fraenkel and Wallen, the population of this study was the second year or eleventh grade students of SMUN 1 in Kuta. This population was, of course, beyond the reseacher's ability to investigate. Therefore, 80 students from two classes were determined as the samples of the study by means of cluster random sampling technique. According to Zuriah (2009), cluster random sampling technique is used when population does not consist of individuals but groups of individuals or cluster. In this case, the population consists of ten classes and two classes were chosen randomly from the population and determined as the samples of this study. Thus, the sample of the study which was taken from the population was considered to be representative. The 80 students were the total number of students from two classes. This was due to the fact that the entire population are presumed to have homogeneous characteristics, namely, they have received the same amount of formal English vocabulary and grammar and practised their English both at school or outside school communities. The total number of the population was 398 students altogether.

According to Fraenkel and Wallen (2009), in educational research, sample is usually described as a fairly small number of population who possess certain characteristics. The concept of sample comes 
from the inability of the researchers to investigate or test all of the individuals in the population. The sample must be the representative of the population and share the same characteristics as the population.

Sampling refers to the process of selecting the individuals. The sampling technique used in this research was cluster random sampling technique. In accordance with the consideration of the head master of SMUN 1 Kuta, two classes were given as the sample of the study. The population of this study was 398 students and the researcher used 80 students in two classes as the sample.

There were four kinds of instruments used in the present research, namely, three tests and one questionnaire. The three tests in English were used to measure the students' vocabulary, grammar and speaking competency, whereas the practice questionnaire was used to get some data about the students' listening and speaking practice. All of the instruments were designed to get the data needed.

The three tests and the questionnaires were distributed to the subjects during regular class hour and with the help of the English teachers. All the data were collected and checked by the researcher himself. Before collecting the data, the researcher asked permission to the headmaster of SMUN 1 Kuta.

The data of vocabulary and grammar were collected by objective tests, namely, tests in the form of objective tests. The data of practice was collected by a questionnaire. Finally, the data of speaking competency was collected by a speaking test. Afterwards, all the data needed for the study were ready to be analysed.

There were three tests and one questionnaire used in the present study. The first test was vocabulary test. This test consists of 40 items in the form of multiple choice items. The test was used to measure the students' mastery of content words, such as, nouns, adjectives, verbs and adverbs. All of the words were taken from the list of words which had been learned by the second year students based on the syllabus. The second test was grammar test which is also in the form of multiple choices and consists of 20 items. The test covered grammar points which had been taught to the second year or eleventh grade students under study. Vocabulary and Grammar are not taught separatedly but they can be learned in readings, dialogues or exercises. The third test was speaking test which is in the form of instruction. There was only one questionnaire, namely, practice questionnaire which contains 20 multiple choice items.

Validity is the degree to which an instrument measures what it is supposed to be measured. Before the researcher collected the needed data, all of the instruments used in the study had to be validated and checked by expert judges. Some statistics formulas were used to measure the validity of each instrument. The result was the instruments became standardized instruments and ready to be used to collect the needed data.

Content validity is the extent to which the instrument measures the intended content area. It refers to the appropriateness of the content of an instrument. In order to check the content validity, the instruments were checked through expert judgement, then they were analysed by using Gregory formula. Gregory in Candiasa (2010) states that if all indicators are represented by the items of the instrument, the instrument has seen a pretty good validity. To determine whether the instruments used reflect the overall content or not, the four instruments were developed by the help and judgements of expert judges.

The four instruments used in this study were checked by two expert judges. The two experts gave judgements toward the content validity of the instruments used. The judges checked and compared the items to the dimensions and indicators stated in the blueprints and put $(\sqrt{ })$ on the column relevant or not relevant. After that, the researcher analyzed the judgments of the two experts by using Gregory's formula.

The tests and questionnaire were administered to the subjects during regular class hours in the second semester with the help of their English teachers. All the data were coded and input into the computer and then analyzed using SPSS 17 for windows. The Statistical Package for Social Science version 17.0. is usually used to analyse any data for statistical purpose. Afterwards, it was continued with data analysis.

Firstly, descriptive statistics such as means, median, and standard deviations were computed to find out the subjects' overall responses. Secondly, the prerequisite tests of hypothesis testing were checked. Dantes (2010) suggests that in order to fulfil the requirements of correlational research data, 
all the data which were already obtained through the data collection should follow some steps and tested by using normality test, linearity test, multicolinearity test, heterocedasticity test and auto correlation test. All the steps or requirements had to be followed, in order to give the right path to further analysis.

Thirdly, Pearson product moment correlations were utilized to determine the relationships between vocabulary, grammar, practice and speaking competency. Finally, multiple regression analysis was used to determine the extent of the contribution between the combination of the predictor variables and the criterion variable.

\section{FINDINGS AND DISCUSSIONS}

The data description was conducted in order to know the characteristics of each variable. It covered the mean score, the highest score, minimum score, standard deviation (SD), variance, median, modus, histogram and the categorization of each variable. Based on the descriptive analysis of the results of tests and questionnaire, the obtained data were as following.

Table 1. Descriptive Statistics of All Variables

\begin{tabular}{|l|r|r|r|r|}
\hline $\begin{array}{l}\text { Variable } \\
\text { Description }\end{array}$ & Vocabulary (V) & Grammar(G) & Practice (P) & $\begin{array}{r}\text { Speaking } \\
\text { Competency } \\
\text { (SC) }\end{array}$ \\
\hline Mean & & & & 67.75 \\
\hline Std. Error of Mean & 72.25 & 69.25 & 57.40 & .945 \\
\hline Median & 1.512 & 2.150 & 1.327 & 70.00 \\
\hline Mode & 75.00 & 75.00 & 58.50 & 70 \\
\hline Std. Deviation & 70 & 80 & 68 & 8.453 \\
\hline Variance & 13.522 & 19.227 & 11.064 & 71.456 \\
\hline Range & 182.848 & 369.684 & 122.420 & 30 \\
\hline Minimum & 60 & 65 & 44 & 50 \\
\hline Maximum & 33 & 35 & 34 & 80 \\
\hline Sum & 93 & 100 & 78 & 5420 \\
\hline
\end{tabular}

There were four points, which were going to be discussed in this discussion session, namely 1) the contribution of vocabulary on students' speaking competency, 2) the contribution of grammar on students' speaking competency, 3) the contribution of practice on students' speaking competency, and 4) the simultaneous contribution of vocabulary, grammar and practice on students' speaking competency.

\section{The Contribution of Vocabulary on Students' Speaking Competency}

The result of analysis showed that there was a significant contribution of vocabulary on students' speaking competency. Using the regression analysis, it was found out that there was a significant and positive contribution of vocabulary on the students' speaking competency. The correlation coefficient (r) was 0.473 , with the determination coefficient $\left(\mathrm{r}^{2}\right)$ was equals to 0.268 . It signified that speaking competency was significantly determined by vocabulary $26.8 \%$, in which its regression equation was $\mathrm{Y}=55.421+0.171 \mathrm{X}_{1}$. The more vocabulary, the higher students' speaking competency was.

In line with the result above, the students who have vocabulary knowledge such as word classes will find it easier to use the words to express their own ideas. Knowing word classes makes students aware of its use and enables them to use it correctly. Word classes can also be seen through grammar point of view. In grammar, it emphasizes more on the rules that follow each word class. While in vocabulary, word classes are used to help the learners recognize the class of any new word they learn. Finally their vocabulary will make them speak more easily. 


\section{The Contribution of Grammar on Students' Speaking Competency}

The linear regression analysis done showed that the coefficient correlations of grammar on the students' speaking competency was $r=0.383$, with the determination coefficient 0.181 or equal to $18.1 \%$. It means that the speaking competency was determined by $18.1 \%$ of the students' grammar with the regression equation $\mathrm{Y}=59.119+0.125 \mathrm{X}_{2}$. It indicated that grammar had a positive and significant contribution on students' speaking competency. The more grammar understood by the students the higher speaking competency that the students had.

Knowledge of grammar enables language users to put words together in the correct order in sentences to communicate ideas and intentions efficiently. It is possible that someone who can produce perfectly correct sentences and communicate efficiently may not be able to explain the rules of grammar. This is true of many speakers of English, including some native speakers. Such people have implicit knowledge of grammar, that is, they know grammar at the level of use. Teachers need to have explicit knowledge of grammar to be able to describe and explain the rules.

\section{The Contribution of Practice on Students' Speaking Competency}

The analysis showed that the contribution of practice on the students' speaking competency was positive and significant. It could be seen from its correlation coefficient. It was 0.343 ; with the significant value was $<0.05$. The $r$ value was higher than $r_{c v}(0.16)$, it means that the correlation was significant. The contribution of language learning strategies to English achievement $\left(\mathrm{r}^{2}\right)$ was 0.169 or $16.9 \%(0.169 \times 100 \%)$. And, its regression equation was $Y=57.114+0.185 \mathrm{X}_{3}$. It means that students' speaking competency was determined by $16.9 \%$ of practice with regression equation $\mathrm{Y}=57.114+0.185 \mathrm{X}_{3}$. Since the contribution was linear positive, It indicated that the more practice done by the students the higher speaking competency the students had.

Practice can be done by the students in the classroom with or without their teachers or outside their school, such as, at home, at the movies, at the beach or at any public place. Formal practice tends to make students learn a language consciously because they do the practice deliberately. On the other hand, functional practice makes the students learn the language naturally. In general, functional practice is better for students and can improve their speaking competency more thoroughly.

\section{The Simultaneous Contribution of Vocabulary, Grammar and Practice on Students' Speaking Competency}

Based on the regression analysis, it was found that the multiple regression equation line of the contribution of the vocabulary $\left[\mathrm{X}_{1}\right]$, grammar $\left[\mathrm{X}_{2}\right]$, and practice $\left[\mathrm{X}_{3}\right]$ on students speaking competency [Y] was $\mathbf{Y}=\mathbf{4 9 . 0 9 6}+\mathbf{0 . 0 9 0} \mathbf{X}_{\mathbf{1}}+\mathbf{0 . 0 5 6} \mathbf{X}_{\mathbf{2}}+\mathbf{0 . 1 4 5} \mathbf{X}_{\mathbf{3}}$, with counted $\mathrm{F}=3.227(\rho<0.05)$, which means that the contribution was significant and linear. In this case the fourth alternative hypothesis which stated that there was a significant positive contribution of vocabulary $\left(\mathrm{X}_{1}\right)$, grammar $\left(\mathrm{X}_{2}\right)$, and practice $\left(\mathrm{X}_{3}\right)$ simultaneously on the English speaking competency $(\mathrm{Y})$ of the second year students of SMUN1 Kuta.

The strength of the contribution of vocabulary, grammar and practice simultaneously on the students' speaking competency was interpreted from the value of correlation coefficient $(\mathrm{r})=0.548$ in the significance level of $\alpha=0.05$, and the determination coefficient $\left(r^{2}\right)$ was 0.326 or $32.6 \%$. The percentage indicated that vocabulary, grammar and practice could simultaneously determine the students' speaking competency $32.6 \%$; meanwhile the rest was influences by other factors. It signified that the more the students' vocabulary, the more grammar understood, and the more frequent practice done by students, the higher the students' speaking competency became.

The result of the study was supported by some researches conducted by the experts.

Blaxell (2013) conducted a research which focused on the need for students to understand and be able to use grammar effectively in order to best support their ability to engage in effective written communication. The result showed that grammar significantly contributed on students communicative skills. Cahyono (2009) considers that teachers have significant roles in developing students' abilities to develop their EFL vocabulary learning. Nurweini in Cahyono (2009) sought to find out whether secondary school graduates knew the 2000 most frequent words and the 808 academic words as the target words. The results of her study indicated that on average, the 324 subjects knew 987 of the 
2000 most frequent words, and 239 of the 808 university words, making up 1226 words in total. The result suggested the need for increasing the number of word repetitions.

Based on the findings above, it could be said that vocabulary should be learned by the students first and they practise it through repetition. When they have enough vocabulary, they can use some grammar to express their ideas and learn to speak and through practice more frequently they improve their communicative skills.

\section{CONCLUSION}

Concerning the result of data analysis and discussion in the previous chapter, it can be concluded that: There was a significant positive contribution of vocabulary on the eleventh grade students' speaking competency of SMUN 1 Kuta. The contribution was categorized as a low contribution. It is indicated that the more the vocabulary was the better speaking competency the students had. In conclusion, vocabulary gave a positive contribution on the English speaking competency of the second year students of SMUN1 Kuta, that is, about $26.8 \%$.

There was a significant positive contribution of grammar on the eleventh grade students' speaking competency of SMUN 1 Kuta. The contribution was considered as a low contribution, and it alsol indicated that the more grammar understood by the students the higher speaking competency the students had. It could be concluded that grammar gave a positive contribution on the English speaking competency of the second year students of SMUN1 Kuta, that is, $18.1 \%$.

There was also a significant positive contribution of practice on the eleventh grade students' speaking competency of SMUN 1 Kuta. The contribution of practice on speaking competency was found to be positive, that is, $16.9 \%$. The contribution was linear positive, but, it is considered to be high enough. It showed that the more practice done by the students the higher speaking competency the students had. In conclusion, practice gave a positive contribution on the English speaking competency of the second year students of SMUN1 Kuta, that is, $16.9 \%$.

There was also a significant positive contribution of vocabulary, grammar and practice on the eleventh grade students' speaking competency of SMUN 1 Kuta. The more vocabulary known, the more grammar understood and the more practice done by the students, the higher their speaking competency became. In conclusion, vocabulary, grammar and practice gave a positive contribution on the English speaking competency of the second year students of SMUN 1 Kuta, that is, $32.6 \%$.

\section{REFERENCES}

Anderson, J.Robert, 2009. Cognitive Psychology and Its Implication, First Edition. New York : Worth Publishers.

Beck, I.L., McKeown, M., and Kucan, L. 2002. Bringing Words to Life : Robust Vocabulary Instruction. New York: Guilford.

Bialystok, E. 1985. The Process of Second Language Acquisition : Focus on Theories. In Gardner, R.C. Social Psychology and Second Language Learning ( ${ }^{\text {st }}$ Ed.), (124 - 144) London Britain : Edward Arnold.

Brown, H.Douglas. 2004. Language Assessment Principles and Classroom Practices, First Edition. London : Longman.

Brown, H.Douglas. 2007. Principles of language learning and teaching, Fifth Edition. New York : Pearson Education.

Cahyono, B. Y. and Widiati, U. 2011. The Teaching of English as a Foreign Language in Indonesia. $\left(\mathbf{1}^{\text {st }}\right.$ ed.). Malang : State University of Malang Press

Campillo, R.M.L. 2014. Teaching and Learning Vocabulary : An Introduction for English Students. Retrieved on May 2014 from : 
http://www.loontar.net/TEACHING\%20AND\%20LEARNING\%20VOCABULARY:\%20AN \%20INTRODUCTION

Celce, Marianne.Murcia. 2001. Teaching English as a Second or Foreign Language, First Edition. London : Heinle \& Heinle.

Chitravelu, N., Sithamparam, S., and Choon, T.S. 2005. ELT Methodology : Principles and Practice, Second Edition. Selangor : Oxford Fajar.

Cohen, L., Manion, L. and Morrison, K. 2007. Research Methods in Education, First Edition. New York : Routledge.

Cowan, R. 2008. The Teacher's Grammar of English, First Edition. Cambridge : Cambridge University Press.

Dantes, Nyoman. 2010. Analisis Varians. Modul Mata Kuliah Metode Statistika Multivariate. Singaraja: Universitas Pendidikan Ganesha.

Djaali, and Muljono, P. 2004. Pengukuran dalam Bidang Pendidikan, Cetakan Kedua. Jakarta : Program Pascasarjana Universitas Negeri Jakarta.

Dulay, H., Burt, M., and Krashen, S. 1982. Language Two (1 ${ }^{\text {st }}$ Ed.), New York : Oxford University Press.

Fraenkel, J. R. and Wallen, N. E. 2009. How to Design and Evaluate Research in Education ( $7^{\text {th }}$ ed.). New York: McGraw-Hill Inc.

Gardner, R.C. 1985. Social Psychology and Second Language Learning ( ${ }^{\text {st }}$ Ed.), London : Edward Arnold.

Harmer, Jeremy. 2008. The practice of English Language Teaching, Fourth Edition. Cambridge : Pearson Education.

Heaton, J.B. 1989. Writing English Language Tests, Second Edition. London : Longman.

Hedge, Tricia. 2008. Teaching and Learning in the Language Classroom, Sixth Impression. New York : Oxford University Press.

Jensen, James C. 2007. Skill Acquiition and Second Language Teaching. Retrieved on May 2014 from : http://kurepo.clib.kindai.ac.jp/modules/xoonips/download.php?file_id=7469

Luoma, Sari. 2004. Assessing Speaking, First Edition. Cambridge : Cambridge University Press.

Long, M. H. and Doughty, C. J. 2009. The Handbook of Language Teaching. (1 ${ }^{\text {st }}$ ed.). Singapore: Willey Blackwell.

Morley, Joan. 2001. Aural Comprehension Instruction : Principles and Practices. In M. Celce-Murcia (Ed.), Teaching English as a second or foreign language (pp. 69 - 86). London: Heinle \& Heinle.

Nunan, David. 2003. Practical English Language Teaching. New York : Mc Graw Hill. 
Peterson, P.W. 2001. Skills and Strategies for Proficient Listening. In M. Celce-Murcia (Ed.), Teaching English as a second or foreign language (pp. 87 - 100). London: Heinle \& Heinle.

Purpura, James. 2004. Assessing Grammar, First Edition. United Kingdom : Cambridge University Press.

Thornburry, Scott. 2002. How to Teach Grammar, Fourth Impression. Malaysia : Pearson Education Limited.

Thornburry, Scott. 2007. How to Teach Vocabulary, Fifth Impression. Malaysia : Pearson Education Limited. 